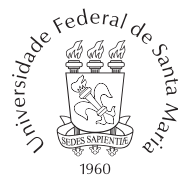

\title{
TRAJETÓRIAS ATRAVÉS DE UM PRISMA: CARIBE, RAÇA E CONSCIÊNCIA OPOSICIONAL EM C. L. R. JAMES E OLIVER C. COX.
}

TRAJECTORIES THROUGH A PRISM: CARIBBEAN, RACE AND OPPO-
SITIONAL CONSCIOUSNESS IN C. L. R. JAMES AND OLIVER C. COX.

TRAJECTOIRES À TRAVERS UN PRISME: CARAÏBES, RACE ET CONSCIENCE OPPOSITIONNELLE CHEZ C. L. R. JAMES ET OLIVER C. COX.

TRAYECTORIAS A TRAVÉS DE UN PRISMA: CARIBE, RAZA Y CONSCIENCIA OPOSICIONAL EN C. L. R. JAMES Y OLIVER C. COX.

Erik Wellington Barbosa Borda* iD https://orcid.org/0000-0001-8624-5903

RESUMO: Este trabalho tem dois objetivos fundamentais. O primeiro é lançar uma interpretação sobre os diferentes rumos que tomam dois autores negros do Caribe, Oliver C. Cox e C. L. R. James. Para esta tarefa, realiza-se um contraste entre as trajetórias iniciais dos autores, cujo período é marcado pelo nascimento de ambos na colônia britânica de Trinidad, no Caribe, em 1901 até a publicação de suas magnum opi; 1948 para Cox e 1938 para James. O segundo objetivo é, em debate com tendências sociológicas voltadas ao estudo de trajetórias intelectuais, argumentar em pró da utilidade de se trabalhar com categorias que colocam os deslocamentos derivados da experiência racial - e as disfunções decorrentes - no princípio da explicação sociológica, e não ao final como resíduos ou eventos. Por fim, é levando isso em consideração que se buscou nos nexos entre as experiências sociais dos autores e os tipos de intervenções propostas por eles explicações acerca da disparidade entre os destinos sociais de ambos.

Palavras-chave: Oliver Cox; C. L. R. James; intelectuais negros; diáspora; pan-africanismo.

\footnotetext{
* Mestre em Sociologia pela Universidade Federal de São Carlos (UFSCar); doutorando em sociologia no Programa de Pós-Graduação em Sociologia da Universidade Estadual de Campinas (Unicamp), Campinas, SP, Brasil; E-mail: ewbborda@gmail.com
} 
Trajetórias através de um prisma:

Caribe, raça e consciência oposicional em C. L. R. James e oliver C. Cox

ABSTRACT: This work has two main objectives. First, it launches an interpretation on the main routes that two black authors from the Caribbean took; Oliver C. Cox and C. L. R. James. For this task, a contrast is made between the initial life of the authors, whose period is marked by their birth in the British colony of Trinidad, in the Caribbean, in 1901 until the publication of their magnum opi; 1948 for Cox, and 1938 for James. The second objective is, by debating with sociological tendencies directed to the study of intellectual trajectories, to argue in defense of the utility of working with categories that place the displacements derived from racial experience - and their resulting dysfunctions - at the beginning of sociological explanation, and not at the end as residues or events. At last, is by taking this into consideration that the article looked for explanations about the disparity of social destinies in both authors, among the links between their social experiences and the kinds of interventions they proposed.

Keywords: Oliver Cox; C. L. R. James; black intellectuals; diaspora; pan-Africanism.

RÉSUMÉ: Cet article a deux objectifs principaux. Premièrement, il lance une interprétation sur les principales routes empruntées par deux auteurs noirs des Caraïbes; Oliver C. Cox et C. L. R. James. Pour cette tâche, un contraste est fait entre la vie initiale des auteurs, dont la période est marquée par leur naissance dans la colonie britannique de Trinidad, dans les Caraïbes, en 1901, jusqu'à la publication de leur magnum opi; 1948 pour Cox et 1938 pour James. Le deuxième objectif est, en discutant avec les tendances sociologiques orientées vers l'étude des trajectoires intellectuelles, de défendre l'utilité de travailler avec des catégories qui placent les déplacements issus de l'expérience raciale - et leurs dysfonctionnements - au début de l'explication sociologique, et pas à la fin comme des résidus ou des événements. Enfin, c'est en prenant cela en considération que l'article cherche, parmi les liens entre leurs expériences sociales et le type d'interventions proposées par eux, des explications sur la disparité q'on trouve entre les destines sociaux des deux auteurs.

Mots-clé: Oliver Cox; C. L. R. James; intellectuels noirs; diaspora; panafricanisme.

RESUMEN: Este trabajo tiene dos objetivos principales. Primero, lanza una interpretación sobre las rutas principales que tomaron dos autores negros del Caribe; Oliver C. Cox y C. L. R. James. Para esta tarea, se hace un contraste entre la vida inicial de los 
autores, cuyo período está marcado por su nacimiento en la colonia británica de Trinidad, en el Caribe, en 1901, hasta la publicación de sus magnum opi; 1948 para Cox, y 1938 para James. El segundo objetivo es, en debate con tendencias sociológicas dirigidas al estudio de las trayectorias intelectuales, argumentar en defensa de la utilidad de trabajar con categorías que sitúan los desplazamientos derivados de la experiencia racial - y sus disfunciones resultantes - al comienzo de la explicación sociológica, y no al final como residuos o eventos. Por último, es teniendo esto en cuenta que el artículo buscó, entre los vínculos de sus experiencias sociales con los tipos de intervenciones que propusieron, explicaciones sobre la disparidad de los destinos sociales de ambos autores.

Palabras clave: Oliver Cox; C. L. R. James; intelectuales negros; diáspora; panafricanismo.

\section{INTRODUÇÃO}

Em 1938, quando parte da Inglaterra para os Estados Unidos, C. L. R. James já tinha atrás de si uma carreira política e intelectual consolidada como um dos principais nomes do Socialismo Internacional e da luta pan-africana. Havia participado ativamente da construção do nascente campo literário de Trinidad e Tobago - à época colônia britânica -, escrito diversos contos e um romance. $\mathrm{Na}$ Inglaterra, publicou textos radicais acerca da revolução mundial e da questão colonial, incluindo uma meia dúzia de livros, dos quais se pode destacar sua obra mais conhecida; Os Jacobinos Negros. Também em 1938, do outro lado do Atlântico, outro trinitino, Oliver C. Cox, terminava seu doutorado em Sociologia pela Universidade de Chicago, acreditando que a vida acadêmica fosse uma atividade mais complacente com sua deficiência: havia contraído poliomielite em 1929 e forçado a passar o resto da vida em uma cadeira de rodas. Após terminar seu doutorado, Cox vê portas fechadas no establishment branco para a dedicação plena que queria à atividade acadêmica, e encontra trabalho na pequena faculdade negra de Wiley, no Texas, onde a carga de trabalho era alta e os salários baixos. Dez anos depois, após a publicação de artigos que, embora em periódicos importantes haviam sido largamente ignorados em seus argumentos, termina a obra que deveria consolidá-lo como um dos principais no- 
mes da Sociologia afro-americana: Caste, class and race. No entanto, o livro deixa de ser impresso logo depois de esgotada a primeira impressão, um ano depois que saiu, em 1948, e tem o mesmo destino de seus artigos. Vistas em conjunto, as trajetórias e as obras de C. L. R. James e Oliver C. Cox podem ser apreciadas como duas modalidades de surgimento de consciências oposicionais radicais negras e caribenhas na vida intelectual da primeira metade do século XX, e dos lugares reservados a essas vozes.

Neste artigo pretendemos debater algumas das variáveis que possibilitaram a consagração de um, James, e a marginalização do outro, Cox, argumentando ao mesmo tempo que há uma estrutura de sentimento que deve ser componente central de uma Sociologia dos Intelectuais que se volte a intelectuais negros na diáspora. De modo a apreendê-la, as descontinuidades de raça e etnicidade devem ser colocadas no princípio da explicação sociológica, o que neste trabalho significou trabalhar com a ideia de "prisma de formação caribenha". Essa ideia, proposta primeiramente pelo intelectual jamaicano Stuart Hall em um comentário acerca de sua própria trajetória, é por sua vez interpretada e desenvolvida por nós enquanto uma consciência oposicional, abordagem que embora distante da corrente pós-colonial que anima parte significativa das reflexões aqui contidas - é um conceito que tomamos de uma Sociologia dos movimentos sociais -, oferece base útil para uma codificação da proposta de Hall, na medida em que centraliza o papel da psicologia para projetos emancipatórios. Em primeiro lugar apresentaremos um breve itinerário político e intelectual conjunto das atividades dos autores até a publicação de suas magnum opi - 1938 para James e 1948 para Cox. Em seguida, lança-se uma interpretação de tais modalidades de inserção intelectual e consciência oposicional, interpretação essa ancorada em uma discussão mais detida que também será feita acerca das implicações de se "levar raça à sério" para os propósitos de nosso tipo de investigação.

Por fim, vale dizer que a escolha dos autores para o contraste justifica-se pelo fato de que ambos são trinitinos, da mesma geração - nasceram no mesmo ano -, tiveram na circulação internacional um dos elementos mais relevantes de suas trajetórias, e produziram 
dentro do que é possível qualificar como uma "tradição radical negra" (Robinson, 2000). Esta, por sua vez, indica o fato de que ambos foram autores negros que trabalharam com/a partir do marxismo, levando preocupações deste a outros lugares e espaços, e deslocando-o consideravelmente. Além disso, ao que tudo indica, nunca se conheceram pessoalmente.

\section{DOIS CARIBENHOS: UM BREVE ITINENÁRIO}

Ambos os autores nasceram em 1901, na colônia insular britânica de Trinidad, no Caribe. Tal como em outras nações que experimentaram o colonialismo e a escravidão, a ilha carregava o peso de sua herança étnico-racial diversa e, principalmente, desigual. De acordo com Daniel Segal (1991), a situação de contato racial na Trinidad pré-independência era caracterizada pela existência de alguns grupos tidos como puros, europeus, africanos e indianos, e por uma grande quantidade de mestiços oriundos das várias combinações possíveis dessas três raças ${ }^{1}$. Segal aponta a centralidade que raça assumia em todas as dimensões da vida social trinitina, era um "idioma que memorava passados particulares e conectava esses passados a grupos sociais contemporâneos"2 (Segal, 1991, p. 84), e enfatiza: "as regras para a classificação de pessoas 'mestiças' eram formais e inequívocas." (Segal, 1991, p. 85) Entre as categorias para a classificação dos grupos emergentes do contato, devemos destacar a de "pessoas de cor" (colored). Da mistura entre brancos e negros teria aparecido não apenas uma população de cor, mas o "mito de origem" indicava uma classe média "de cor" que preencheria o hiato social entre as classes altas (brancas) e baixas (negras). Mas raça não operava aqui simplesmente como um espelho da economia política, ela a representava e a configurava, o que é algo bem diferente (Segal, 1991, p. 83). Isso significa que o status um pouco superior adquirido pelas classes médias de cor em Trinidad - que lhes permitia o acesso até mesmo a profissões de manutenção do regime colonial - estava

1 De acordo com Segal (1991, p. 85), existiam cerca de 15 permutações possíveis no sistema de consideração racial em duas gerações de uniões entre as três principais raças de Trinidad.

2 Tradução livre.

3 Tradução livre. 
Trajetórias através de um prisma:

Caribe, raça e consciência oposicional em C. L. R. James e oliver C. Cox

longe de ser fixo, e a decadência real e simbólica era um espectro sempre presente na vida dessas famílias. Uma armadura contra a decadência era a respeitabilidade.

C. L. R. James e Oliver C. Cox nasceram em famílias desse estrato social, e foram impactados em grande medida por essas contradições. O pai de James era um professor, à época uma posição de alta estima social, uma vez que apenas o padre ou o ministro gozavam de status mais alto (Buhle, 1988. p. 15). Sua mãe era uma mulher extremamente culta e leitora ávida, e segundo diz James (1983), com frequência convidada para almoços por brancos da região, o que na Trinidad colonial não era pouca coisa. No entanto, o jovem James devia ser protegido das cruas intrusões do mundo que ameaçavam esse prestígio. A casa de sua família em Tunapuna - cidade onde nasceu e passou a infância ${ }^{4}$ - se situava muito próxima a um campo de críquete, e da janela James podia acompanhar as partidas. Um dos jogadores era um sujeito rude e iletrado, qualificado de "vagabundo" pelas tias de James, que arrastava seus tacos de lá pra cá em frente à casa, chamado Matthew Bondman. Bondman, cru e vulgar, personificava essas intrusões, a ameaça à respeitabilidade das classes médias de cor em Trinidad. Mais de meio século depois, em 1963, James discutiria (1983) a figura de Bondman, que apesar da rudeza, com um taco na mão era todo "graça e estilo". Tal fato demonstra que o acesso à vida das classes populares tinha às vezes resultados inesperados nas trajetórias intelectuais. Bondman e a arte que em- $^{5}$ preendia nas partidas de críquete que James acompanhava aos seis anos de idade de sua janela se tornariam, para o autor, uma espécie de metonímia do potencial civilizatório das classes populares caribenhas, potencial este obliterado pelas condições e contradições impostas pelo regime colonial.

A família de Oliver Cox era, em relação a de James, mais abastada. Tinha uma casa na capital, Port of Spain, e outra de verão em

4 Para Kent Worcester (1996), um dos principais biógrafos de James, o autor teria nascido na vila de Caroni. Selwyn Cudjoe destaca que apesar dessa informação, James sempre afirmou ter nascido em Tunapuna, e nunca contradisse as informações biográficas apresentadas por Margaret Busby nos três volumes de suas obras escolhidas (Cudjoe, 2004, p. 128).

5 Deve-se ter em mente que, para James, o críquete é muito mais que um esporte. Não apenas é um tipo de arte como também envolve dimensões que no geral se poderia facilmente argumentar que "não são críquete". Tal se dá pois James via no críquete "um dos modos civilizados pelos quais a luta anti-imperialista era jogada" (Hall, 1992, p. 13). 
uma fazenda no centro da ilha. Seu pai era primeiramente capitão de uma escuna da receita, um navio de fiscalização do governo, e depois um agente de impostos do regime colonial. Herbert Hunter (1987) comenta que essas obrigações faziam do pai de Oliver Cox, William Cox, não tão atencioso com seus filhos como quisera, e embora fosse exigente com resultados - de novo o tema da respeitabilidade -, o gosto pelo estudo havia sido passado a seus filhos por ser irmão, Reginald Vidale, também professor e posteriormente diretor da Escola para meninos St. Thomas, onde Cox adquire sua formação primária.

As formas de ascensão ou manutenção do status social para as classes médias de cor, portanto, em grande medida dependiam de trunfos morais e culturais - incluídos nestes o afastamento do "perigo" de enegrecer a raça -, e a situação política tinha seu papel nesse processo. Havia uma reserva das posições-chave do regime para a elite branca e colonial. $\mathrm{O}$ acesso à educação era regulado por meio de uma inflação artificial das taxas nas escolas secundárias de Trinidad, de modo que para famílias como as de Cox e James restava a disputa pelas poucas bolsas oferecidas a alguns jovens brilhantes da colônia (McAuley, 2004, p. 16). Se não se fosse bem sucedido nesses exames de bolsas, não haveria alternativa educacional, pelo menos em Trinidad. A ilha possuía dois colégios que ofereciam formação secundária, o St Mary's e o Queen's Royal College. Este oferecia apenas quatro bolsas anualmente para toda a colônia, e com a idade máxima para prestar o exame de 12 anos. James, em 1910, é aprovado em primeiro lugar e torna-se o mais jovem a conseguir uma das bolsas. Oliver Cox, apesar da pesada rotina estudos exigida por seu pai e da educação passada por seu tio, não consegue uma posição em nenhum deles. Isso explica em parte o porquê de ter deixado o Caribe muito antes de James.

É difícil falar de intelectuais afro-caribenhos sem falar na experiência do exílio. Gerações de pensadores, ativistas, poetas e escritores das antigas Índias Ocidentais se viram obrigados a deixar suas terras, muitas vezes para nunca mais regressar. ${ }^{6}$ Esses deslocamentos e a consciência decorrente refletiram em suas obras e projetos. Para

6 Uma importante reflexão sobre o tema do exílio e seu papel na experiência social de uma geração de pensadores caribenhos na Inglaterra pode ser apreciada em The Pleasures of Exile, de George Lamming (1992). 
Trajetórias através de um prisma:

Caribe, raça e consciência oposicional em C. L. R. James e oliver C. Cox

quem vinha da periferia colonial, era evidente que o Mundo era visto de outro modo, que os discursos que lhes eram oferecidos não tinham o mesmo significado, que eram decompostos e rearticulados em uma nova combinação para se adequar a uma realidade humana muito diferente. Era como se tudo passasse através de um prisma.

Cox parte aos EUA em 1919, com 18 anos. Era tradição da família que os filhos estudassem nos Estados Unidos. Um de seus irmãos que havia migrado anos antes morava em Chicago, e Cox passa a viver com ele. No ano seguinte, começa a preparar-se para o ingresso na Universidade, e como não havia cumprido o ensino secundário em seu Caribe natal, matricula-se no Central YMCA High School, onde se forma em 1924, e em seguida no Crane Junior College (ou possivelmente no Lewis Institute) 7 , e em 1926 ingressa na Northwestern University, onde adquire em 1928 o desejado diploma em Direito que buscava quando deixou o Caribe. Entretanto, em 1929 contrai poliomielite, doença que acaba por paralisar suas pernas, e vê assim a realização de seus planos de vida severamente comprometida. Politicamente, esse período inicial de Cox nos Estados Unidos não parece tê-lo afetado de maneira significativa, ao ponto de um dos principais comentadores de sua obra chamar esse período de sua "fase pré-política e pré-crítica" (McAuley, 2004).

Por causa da poliomielite, Cox opta por seguir a carreira acadêmica, uma vez que via nesta uma necessidade menor de "jogo de pernas". Acreditava que a área de Economia lhe pudesse dar instrumentos para explicar a Grande Depressão, e ao se deparar com uma ausência dos instrumentos que buscava, curiosamente decide apos-

\footnotetext{
7 Há aqui um conflito de informações entre os dois principais biógrafos e comentadores da obra de Cox. De acordo com Herbert Hunter, Cox teria se formado no YMCA em 1923 e, em seguida, ingressado no Lewis Institute, onde teria adquirido uma formação complementar com ênfase em História e Economia em 1925 (Hunter, 1983, p. 250). Hunter parece ter baseado essas informações nos boletins da Northwestern University (onde Cox estuda Direito). Entretanto, Christopher McAuley - vale dizer que escrevendo cerca de 20 anos depois - afirma que Cox se forma em 1924, e que sua presença no Lewis Institute seria apenas para a aquisição de uma licença de estenógrafo (McAuley, 2004, p. 243). Essa informação, de acordo com o autor, é decorrente de um formulário escrito pelo próprio Oliver C. Cox já no fim de sua vida, quando passa a lecionar na Wayne State University, e em tal formulário Cox não menciona nem o Lewis Institute nem que se formou em 1923. Para McAuley, na verdade, Cox teria estudado um curto período de tempo no Crane Junior College (hoje Malcom X College), onde adquire um diploma de associado. Além disso, há outro conflito de informação no que diz respeito a data de ingresso de Cox no curso de Direito da Northwestern. Hunter, em seu artigo de 1983, afirma que Cox ingressa em 1926 e termina em 1928, mas em um trabalho de 1987, o mesmo autor afirma que Cox ingressa em 1927 e termina em 1929 (HUNTER, 1987. p. xix). Como McAuley também opta por 1926 como o ano de ingresso e 1928 como de término, esta será a cronologia adotada aqui.
} 
tar na Sociologia. : "Eu senti que se a Economia não explicava o que eu queria saber, se a economia não explicava a chegada da grande depressão, se a economia não me ajudava a entender aquela grande mudança econômica, então senti que não precisava dela. Assim, eu mudei para a Sociologia." (Cox apud Hunter, 1983, p. 251) Dizemos que se tratou de uma manobra curiosa pois a Sociologia que se fazia na Universidade de Chicago até então estava distante dos interesses sociológicos mais "continentais" de Cox".

Conclui, assim, um mestrado em Economia pela Universidade de Chicago ao qual se segue um doutorado em Sociologia pela mesma instituição, em 1933. O tema de sua tese, defendida 5 anos depois, marcaria a incursão pela temática que perseguiria seu destino social: as relações raciais ${ }^{10}$. Terminado o doutorado, estava apto em termos de currículo para conseguir uma posição onde desejasse, mas consegue emprego apenas na pequena faculdade negra de Wiley, em Marshall, Texas. Ademais das limitações financeiras e excesso de carga docente, o acesso de Cox em Wiley a redes intelectuais era precário, e trabalhava em relativo isolamento. À exceção de seu amigo, o poeta Melvin B. Tolson ${ }^{11}$ que lecionou em Wiley entre 1924 e 1947, não havia nenhum outro nome de peso da cultura ou intelectualidade negras em Marshall nesse momento. Apesar disso, Cox foi extremamente prolífico durante a curta temporada em Wiley, que deixa em 1944 para assumir uma vaga na grande instituição de educação industrial de Booker T. Washington, o Tuskegee Institute, no cinturão negro do Alabama. De sua produção desse período se destacam as primeiras avaliações críticas da chamada - o título foi cunhado por Cox - Escola de Castas de relações raciais. Até Caste,

8 Tradução livre.

9 "A sociologia de Chicago caracteriza-se antes de mais nada pela pesquisa empírica [...]. A Escola de Chicago é uma sociologia urbana, que realizou uma série impressionante de estudos sobre problemas que enfrentava a cidade." (Coulon, 1995, pp. 7-8)

10 A tese, orientada por William F. Ogburn, intitulava-se Factors Affecting the Marital Status of Negroes in the United States. Ogburn foi um importante sociólogo americano branco, e suas abordagens enfatizavam, de modo geral, os métodos quantitativos. Esse fator foi influente em Cox, e que de certa forma contribuiu para seu caráter de "outsider" dentro do Departamento de Sociologia da Universidade de Chicago. Para mais informações sobre Ogburn ver (Laslett, 1991). Sobre o doutorado em Sociologia de Cox em Chicago, ver (Johnson, 2004).

11 Sobre a obra de Melvin B. Tolson ver Tolson Jr (1990). Há também o filme O Grande Desafio (The Great Debaters) (2007) produzido por Oprah Winfrey e estrelado por Denzel Washington, que narra o grupo de debates organizado pelo poeta e professor de Wiley durante os anos 30, e que conseguiu, apesar de condições adversas, vitórias significativas contra instituições de prestígio negras e brancas. 
Trajetórias através de um prisma:

Caribe, raça e consciência oposicional em C. L. R. James e oliver C. Cox

Class and Race em 1948, sua Magnum opus e que encerra o período biográfico ao qual nos voltamos neste trabalho, Cox publicou cerca de onze artigos críticos aos expoentes da tendência e a outros grandes nomes das Ciências Sociais americanas contemporâneas, como Ruth Benedict e Robert Park. "A reputação de Cox como sociólogo começou a crescer enquanto ele estava em Tuskegee, e foi nesse momento que sua crítica radical das noções prevalentes das relações de casta, classe e raça começou a lhe render o rótulo de 'marxista'.,'12 (Hunter, 1987. p. xxiv)

Enquanto isso, no Caribe, James experimenta a educação de elite do que qualifica como "pequeno Éden”, o Queen's Royal College, em um momento central para as atividades posteriores do autor. Durante esse período, ele começa a escrever artigos e contos para periódicos, e demonstra germes de rebelião contra o universo da respeitabilidade da pequena classe média de cor trinitina. Diferentemente de Cox, James manteve abertas algumas vias de acesso à vida as classes populares - como ao críquete e ao calypso. Após graduar-se no QRC, James organiza grupos literários que aos poucos conformaram uma crítica cultural no Caribe colonial. Não menos importante, acompanha de perto as atividades políticas da Associação de Trabalhadores Trinitinos (TWA), escrevendo para o jornal do movimento e a biografia de seu líder, Arthur Cipriani.

C. L. R. James deixa Trinidad e desembarca em Plymouth, na Inglaterra, no dia 18 de março de 1932. Sua viagem fora motivada pelo objetivo de seguir a carreira literária, uma opção improvável de ser realizada em seu Caribe natal. Em pouco tempo na metrópole a literatura foi extraída de si e substituída pela política. James havia acertado um plano no ano anterior com seu amigo, o jogador de críquete trinitino Learie Constantine, de que ele se juntaria a Constantine e sua família em Nelson. No entanto, é Londres sua primeira residência, pelo menos até terminar o dinheiro que havia guardado. Esses primeiros três meses que passa em Londres são importantes do ponto de vista biográfico pois é possível distinguir neles atitudes particulares de James, que terão futuramente papel decisivo em seu destino social.

12 Tradução livre. 
Essas atitudes são captadas em uma série de artigos que o autor escreveu para o jornal de Trinidad Port of Spain Gazette. Em alguns dos artigos, James revela a aparente pouca importância que relegava às experiências pessoais com o racismo ${ }^{13}$. Em outros, mais importante, revela-se o senso de pertencimento e herança que o autor nutria pela civilização ocidental. Em sua temporada em Londres, James viveu no boêmio bairro de Bloomsbury. A atmosfera artística e intelectualizada do bairro fez lhe sentir como "um peixe na água". "Mesmo que eu veja a vida de Bloomsbury pela coisa secundária que ela é, ainda assim tanto por instinto quanto por treinamento eu pertenço a ela e me encaixei tão naturalmente quanto um lápis se encaixa em um apontador. Pássaros de uma mesma pena voarão juntos."14 (James, 2003, p. 54)

Após o período em Londres, James se dirige à cidade de Nelson, em Lancashire, onde passa a viver junto com Learie Constantine por dez meses, até voltar a Londres em março de 1933. Se James não havia sido impressionado por Londres, Nelson mudaria sua opinião acerca da Inglaterra e do povo inglês ${ }^{15}$. Lancashire foi durante o século XIX um dos principais núcleos da explosão da indústria têxtil britânica - e por consequência de sindicatos -, e ademais, particularmente em Nelson havia tradições democráticas antigas enraizadas em preceitos religiosos, tradições que enfatizavam o autogoverno e a autoeducação (Høgsbjerg, 2014, p. 39). Tal contexto social estabeleceu um terreno fértil para ideias radicais, que iam desde vertentes liberais ao socialismo do Independent Labour Party, de modo que a cidade era conhecida por apelidos como Red Nelson ou, por vezes, Little Moscow ${ }^{16}$.

13 Ele reconhece que "é um grande assunto, e vou tocá-lo algum dia do modo que ele merece." (James, 2003, p. 83) O tema aparece também de maneira candente três décadas depois em $B e$ yond a Boundary (1983), quando James discute a recusa de seu alistamento para lutar na Primeira Guerra por ser "muito escuro". "Nem machucou por muito tempo porque por muitos anos essas cruas intrusões do mundo que nos cercava foram excluídas. Eu nem sequer havia sido ferido, pois nenhuma cicatriz foi deixada." (James, 1983, p. 40)

14 Tradução livre.

15 "Mas para encontrar algo do qual o povo inglês realmente é feito, o que o distingue de nosso povo em casa, além de mais oportunidades e uma civilização mais antiga, eu tive que encontrar não em Londres, mas em uma pequena cidade no norte da Inglaterra, onde me encontro atualmente, uma pequena cidade chamada Nelson" (James, 2003. pp. 122-123, tradução livre).

16 A página oficial do governo da cidade destaca essa face de sua história: "Essa alta concentração da população em uma liderança comercial inevitalmente levou a uma forte tradição sindical na cidade, e a eventual formação da Nelson Weaver's Association (Associação de tecelóes de Nelson), a qual, em 1912, tinha quase 12,000 membros. Houve logo suporte ao Partido Trabalhista, 
Trajetórias através de um prisma:

Caribe, raça e consciência oposicional em C. L. R. James e oliver C. Cox

A estada de James na Inglaterra, logo, foi o principal momento de radicalização política em sua trajetória ${ }^{17}$, e um dos elementos responsáveis foi seu contato com o marxismo, ou melhor, do marxismo via o trotskismo. Ainda que afirme ter sido "Thackeray, e não Marx, que teve a maior responsabilidade sobre ${ }^{18}$ " ele (James, 1983, p. 47), o marxismo foi uma influência indispensável. Esse contato se deu por meio das discussões com os pequenos e relativamente desorganizados círculos marxistas. Vale destacar, em particular, a tendência revolucionária que rompe em 1934 com o já dissidente Independent Labour Party (ILP) e se autodenomina como um grupo marxista (Bogues, 1997). Assim, o contato com o grupo trotskista e com as classes trabalhadoras de Nelson foram centrais. Em suas palavras: "a escrita de ficção fora drenada de mim e substituída pela política. Eu me tornei um marxista e um trotskista."19 (James, 1983, p. 149) Em sentido inverso, seus dotes literários, sua profunda erudição e conhecimento dos pilares da tradição ocidental, seu dom de orador, enfim, sua formação cultural caribenha de elite, foram acréscimos essenciais para o movimento trotskista.

É na Inglaterra também que James toma contato mais intenso com o pan-africanismo. Um dos momentos críticos desse contato se apresenta em 1934, com a crise da Abissínia (atual Etiópia) e posterior invasão do país pela Itália de Mussolini, no dia 3 de outubro de 1935. O evento causa um furor enorme de indignação não apenas em círculos intelectuais negros. T. Ras Makonnen comenta que "quando os italianos entraram em Adis Abeba, relatou-se que crianças na escola choraram na Costa do Ouro [atual Gana]." ${ }^{20}$ (Makonnen apud Kelley, 2012, p. 10) Aos ativistas negros na Inglaterra não houve muita escolha a não ser reagir contra a violência imperialista. A reação vinculou James como ponta de lança ao círculo pan-afri-

que ganhou controle político da unidade administrativa já em 1905, e novamente ao final dos anos 1920. A militância dos membros do sindicato nos bloqueios de 1911/1912 e 1928, e os protestos voláteis durante esta última, levaram a cidade a ser conhecida como 'Pequena Moscou'a partir de um relatório da imprensa local. A verdade, entretanto, é que a descrição é injusta, pois embora o socialismo fosse forte havia pouco suporte ao comunismo. O nome alternativo, 'Vermelha Nelson', era provavelmente mais preciso." (Council, 2017, Online, tradução livre)

17 Para Christian Høgsbjerg, foi na Inglaterra, e não nos Estados Unidos - como às vezes se costuma afirmar, que ocorre a radicalização de James (Høgsbjerg, 2014).

18 Tradução livre.

19 Tradução livre.

20 Tradução livre. 
canista, cuja organização International African Friends of Abyssi$n i a^{21}$ (IAFA) - que tinha como outros membros Jomo Kenyatta, I. T. A. Wallace Johnson, Amy Ashwood Garvey, T. Ras Makonnen e Albert Marryshaw - fora presidida por James (Kelley, 2012, p. 12). Os membros dessa organização, frustrados com falta de vontade da Liga das Nações de tomar uma atitude contra Mussolini, reagrupam-se e formam após a crise etíope o International African Service Bureau (IASB). Esta, por sua vez, foi responsável por uma atividade de propaganda na Inglaterra dos anos 1930 que ventilou a unidimensionalidade dos debates marxistas eurocêntricos centrados na classe. Apesar de pequeno, o grupo e seu periódico, o International African Opinion - editado por James entre julho e outubro de 1938, quando parte para os Estados Unidos - foram profundamente influentes, trazendo à tona o tema do colonialismo em um momento no qual essa questão corria o risco de ser obliterada por temas "mais urgentes" aos europeus como o nazi-fascismo e a perspectiva de uma guerra (Kelley, 2012). A questão da Etiópia, e o contato com o pan -africanismo, configura assim um ponto de virada no pensamento de James, uma compreensão que produziria sua magnum opus $O s$ Jacobinos Negros (Kelley, 2012, p.14) em 1938, que por sua vez encerra o período de recorte biográfico deste artigo.

A breve exposição acima apresentou os momentos e ingressos a redes intelectuais que Cox e James tiveram na primeira fase de suas vidas. Apesar de compreender um período relativamente curto, são suficientes enquanto material explicativo a ser trabalhado acerca da consagração de um enquanto um dos principais nomes do pensamento afrodiaspórico e marginalização do outro do campo sociológico norte -americano. O ingresso de James na esfera dos círculos trotskistas e do movimento pan-africanista na Inglaterra, e de Cox na Sociologia Americana da primeira metade do século $\mathrm{XX}$, revelam duas modalidades de vozes oposicionais negras e dos lugares reservados a elas, e revelam também os impactos que diferentes dimensões institucionais e acesso desigual a redes intelectuais tiveram sobre a produção de cada um deles. Na seção seguinte nos voltaremos a discutir esses elementos.

$21 \mathrm{O}$ nome da associação é depois modificado para International African Friends of Ethiopia (IAFE) (Kelley, 2012). 
Trajetórias através de um prisma:

Caribe, raça e consciência oposicional em C. L. R. James e oliver C. Cox

\section{O PRISMA E SOCIOLOGIA: UMA PROPOSTA}

As exposições biográficas feitas na seção anterior introduziram brevemente o material que será utilizado para o contraste entre as trajetórias iniciais de James e Cox. É nossa preocupação aqui, porém, que a maneira de se realizar essa tarefa esteja atenta à questão racial como variável estruturante de um trabalho teórico descolonizado. Nesse sentido, menos que uma aplicação formal de alguma vertente analítica do que costuma se chamar de abordagens externalistas para o estudo de círculos intelectuais (Pontes, 1997), é nosso objetivo aliar a ela a ideia de prisma, mais em termos de perguntas levantadas do que em termos de respostas oferecidas.

A ideia de um "prisma de formação caribenha" é apresentada pela primeira vez por Stuart Hall (2007) em uma conferência realizada na Universidade das Índias Ocidentais acerca de sua própria trajetória. De acordo com o autor, sua visão acerca de problemáticas que poderiam ser classificadas como iminentemente "britânicas" fora feita desde um outro lugar, lugar esse que nomeia de prisma de formação caribenha. Hall se refere aqui ao seu senso de não-pertencimento, à percepção de estar às margens de uma estrutura de sentimento $^{22}$ assentada na britanicidade. Embora Hall não desenvolva essa noção, ela pode nos ser útil para a interpretação das intervenções e trajetórias de autores do Caribe, enquanto a manifestação de um tipo particular de consciência oposicional.

O conceito consciência oposicional, por sua vez, decorre da Sociologia dos movimentos sociais. Segundo Jane Mansbridge,

Dizemos que membros de um grupo que outros tradicionalmente trataram como subordinados ou desviantes possuem uma consciência oposicional quando eles clamam sua identidade previamente subordinada como uma identificação positiva, identificam injustiças feitas a seu grupo, demandam mudanças na política, economia ou

22 O conceito de estruturas de sentimento origina-se dos trabalhos do teórico cultural Raymond Williams, influente sobre diversos pensadores da chamada Nova Esquerda britânica e dos Estudos Culturais. Com o conceito, Williams tenta chamar a atenção para o caráter eminentemente social dos afetos, principalmente em sua dimensão produtiva de obras culturais. "Não sentimento contra pensamento, mas o pensamento tal como é sentido e o sentimento tal como é pensado: consciência prática de um tipo presente, em uma continuidade vivida e inter-relacionada." (WILLIAMS, 1977. p. 132. Tradução livre.) 
sociedade para retificar essas injustiças e veem outros membros de seu grupo como compartilhadores do interesse de retificar essas injustiças. ${ }^{23}$ (Mansbridge, 2001, p. 1)

Nossa opção pelo uso do conceito repousa em sua utilidade, no fato de ser conciliável com algumas perspectivas filosóficas que emergiram do próprio Caribe em vistas dos problemas políticos, ontológicos e epistemológicos específicos dessa região. Importante aqui é a obra do psiquiatra martiniquenho Frantz Fanon (2008; 2005), para quem é possível afirmar a existência de um espaço ontológico distinto construído para os sujeitos negros em um mundo branco. Segundo Fanon, não há uma dialética humana possível entre brancos e negros pois estes últimos estão fixados pelo olhar colonizador dos primeiros. Não obstante, o espaço ocupado pelos colonizados é não só ontológico, mas é também político ${ }^{24}$, e tampouco deixa de informar nossas categorias de entedimento e produção de conhecimento (Maldonado-Torres, 2007). O fato de ser político significa que sua destruição é possível, e que ela ocorre cotidianamente, seja em situações individuais ou eventos históricos; incluídos aqui lutas por emancipação nacional e as não raras revoltas de escravos que ocorreram durante as colonizações de África e América.

A ideia da zona de não-ser fanoniana, esse espaço ontológico negativo ao qual tenta-se colocar os sujeitos colonizados, foi apropriada recentemente por Neil Roberts (2015) em vistas de sua preocupação com as implicações dessa ideia para a Filosofia Política, particularmente no tocante à dialética entre liberdade e escravidão. Para Roberts, a marronage - prática de fuga generalizada de escravos típica do Caribe - é útil para se repensar as modalidades possíveis do que significa ser ou estar "livre". Entre os tipos de marronage que o autor reconhece está a marronage sociogênica, cujo termo, "sociogenia" ${ }^{25}$ se origina da crítica fanoniana ao pensamento 23 Tradução livre.

24 Em sua obra mais política, escrita pouco antes de sua morte, em 1961, Fanon descreve essa dimensão: "A zona habitada pelos colonizados não é complementar à zona habitada pelos colonos. Essas duas zonas se opõem, mas não a serviço de uma unidade superior. Regidas por uma lógica puramente aristotélica, elas obedecem ao princípio de exclusão recíproca: não há conciliação possivel, um dos termos é demais." (Fanon, 2005, p. 55) Aqui, Fanon refere-se tanto ao espaço ontológico, as zonas de ser e de não-ser do regime colonial, como de fato ao espaços físicos habitados pelos seres humanos na situação colonial.

25 Deivison Faustino nota que Fanon emprega o termo "sociogenia" apenas uma vez, e em seu pri- 
Trajetórias através de um prisma:

Caribe, raça e consciência oposicional em C. L. R. James e oliver C. Cox

psicanalítico. De acordo com Roberts:

Sociogênese é a ideia de que as experiências vividas moldam nosso mundo social e estruturam nossas ordens civis e políticas. É a noção de que os humanos trazem o estado de sociedade à existência através de medidas objetivas e subjetivas. Processos e avaliações humanas ocorrem em um mundo assentado sobre a linguagem, seu significado, e resistência à inércia. Sociogênese é, em suma, o prisma que captura o processo de fuga da zona de não-ser. ${ }^{26}$ (Roberts, 2015, p. 119)

Assim, para o autor há um tipo particular de fuga que implica a destruição do espaço ontológico fanoniano da zona de não-ser. Considerando também a dimensão epistemológica da crítica fanoniana, acreditamos ser possível falar em fugas intelectuais, por meio das quais autores caribenhos tentaram refletir sobre suas condições, escapar delas em pensamento e desmantelar os mecanismos intelectuais da opressão.

Para Roberts, assim, a zona de não-ser está longe de ser um espaço de morte social, afinal pensar desse modo

nega a significância da psicologia para liberdade, tornando incapaz de explicar como escravos são capazes de ficarem livres fisicamente fora das ações e intenções dos agentes escravizadores. Ela também não consegue explicar a metafísica da liberdade, desse modo oferecendo uma consideração incompleta do tornar-se livre no que tange à constituição do self e as alterações drásticas da estrutura social. ${ }^{27}$ (Roberts, 2015, p. 117)

Como sinalizamos mais acima, o conceito de consciência oposicional é conciliável justamente com essa ideia de metafísica da liberdade elaborada por Roberts com base na obra de Fanon. Acreditamos que o prisma de formação caribenha de que fala Stuart Hall, enquanto uma consciência oposicional, pode ser interpretado como uma fuga meiro livro, Pele negra, máscaras brancas. Não obstante, foi o suficiente para que diversas interpretações da obra do autor fossem realizadas por esse crivo (Faustino, 2014, p. 55). Em termos gerais, o termo remete à discussão a respeito da força que a dimensão sócio-histórica exerce sobre o psiquismo. "Veremos que a alienação do negro não é só uma questão individual. Ao lado da filogenia e da ontogenia, há a sociogenia. De certo modo, para responder à exigência de Leconte e Damey, digamos que o que pretendemos aqui é estabelecer um sócio-diagnóstico." (Fanon, 2008, p. 28)

26 Tradução livre.

27 Tradução livre. 
epistemológica da zona de não-ser, e se assim considerado, pode lançar luz sobre os modos pelos quais autores negros caribenhos assumiram a tarefa de deslocamento dos discursos universalizantes europeus que não lhe reservavam um espaço ontológico apropriado.

É possível identificar esse gesto tanto nas obras de C. L. R. James quanto de Oliver C. Cox. O livro de James Os Jacobinos Negros (2010), por exemplo, é uma afirmação radical da agência do contingente escravo em relação à conquista de sua liberdade e da própria construção da modernidade. Caste, class and race de Cox (1948), por sua vez, desvela as formas por meio das quais se mantinham intactas ao nível de explicação sociológica a desigualdade racial no Sul dos EUA. Em ambos os casos há um deslocamento de perspectivas que não tem nada de inato, mas origina-se da trajetória singular desses autores. Mas a identificação da produção social desses deslocamentos é impulsionada pela noção de prisma, que analiticamente os destaca.

Queremos deixar nítido que a principal vantagem de nossa opção em relação a outras abordagens está no lugar que as disrupções ocupam na explicação sociológica. Afinal, mesmo o uso de categorias como diáspora podem às vezes ser usados com fins diversos, algo para o qual Stuart Hall chama nossa atenção:

Embora eu ache produtivo pensar em termos de uma diáspora, o conceito de diáspora pode certamente ser usado para exatamente o fim oposto: não para confrontar, mas para disfarçar, evitar ou reprimir tais tipos de dinâmicas emocionais internas e os traumas resultantes envolvidos. O grande valor do pensamento diaspórico, tal como eu o concebo, é que longe de abolir tudo que se recusa a encaixar ordenadamente em uma narrativa - os deslocamentos -, coloca as disfunções em primeiro plano. ${ }^{28}$ (Hall, 2017, p. 171)

Optamos, assim, por trabalhar em consonância com as reflexões de Hall sobre sua formação caribenha, e colocar os deslocamentos no princípio, seja no tocante às intervenções políticas e intelectuais dos autores, seja à respeito de nossa própria interpretação desses processos.

Esperamos mostrar a seguir que, não obstante o ponto de vantagem oportuno promovido por esse tipo particular de consciência 28 Tradução livre. 
oposicional nos autores estudados, o prisma de formação caribenha, deve ser a ele combinado um estudo dos horizontes de possibilidade para suas manifestações. Essa é a pedra de toque de nossa explicação acerca dos rumos distintos das trajetórias de James e Cox, a saber, o lugar reservado para essas vozes em diferentes contextos. Trata-se, enfim, de considerar no estudo de intelectuais negros a experiência da dupla consciência e de uma estrutura de sentimento decorrente da diáspora como variáveis sociológicas. Ou seja, "levar raça a sério". Um dos modos de apreender isso é pensar em termos das perguntas que essas duas posições, as análises externalistas e a perspectiva do prisma, colocam, que por sua vez desvelam problemáticas distintas.

Pierre Bourdieu, em um curso lecionado no Collège de France, questiona a possibilidade de existência de um ato desinteressado (Bourdieu, 1996a). O edifício teórico construído pelo autor, que por motivos de espaço não nos deteremos aqui, orbita uma constelação de problemáticas que envolvem as lógicas sociais que orientam as circulações individuais por espaços de poder. Entre esses espaços, é claro, os mundos intelectual, artístico e político ocupam um lugar privilegiado. A busca pela revelação dessas lógicas leva Bourdieu a responder negativamente a pergunta colocada em seu curso, ao menos no que diz respeito à possibilidade de um desinteresse pleno: "se o desinteresse é sociologicamente possivel, isso só ocorre por meio do encontro entre habitus predispostos ao desinteresse e universos nos quais o desinteresse é recompensado." (Bourdieu, 1996a, p. 153) Discutindo um objeto distinto, a saber, os movimentos sociais, Jane Mansbridge (2001) coloca-se outra pergunta: como podem ser capazes os seres humanos de sacrificar suas vidas pelo grupo? Ambos os autores têm respostas para si próprios e teriam para a pergunta do outro, mas como dissemos, nosso interesse neste artigo não está nas respostas, mas nas perguntas que levaram as duas discussões a lugares diferentes.

É comum em trabalhos sobre relações raciais destacar o que Du Bois chama de dupla consciência, que marca a experiência afrodiaspórica. 
É uma sensação estranha, essa dupla consciência, essa sensação de estar sempre a se olhar com os olhos de outros, de medir sua própria alma pela medida de um mundo que continua a mirá-lo com divertido desprezo e piedade. E sempre sentir sua duplicidade - americano, e Negro; duas almas, dois pensamentos, dois esforços irreconciliados; dois ideais que se combatem em um corpo escuro cuja força obstinada unicamente impede que se destroce. (Du Bois, 1999, p. 54)

A percepção da duplicidade não escapou a muitos outros pensadores do Atlântico negro. Fanon também destaca que quem faz o homem negro é o homem branco, que "o conhecimento do corpo é unicamente uma atividade de negação. É um conhecimento em terceira pessoa." (Fanon, 2008, p. 104) A possibilidade de ser humano, ser um francês ou mesmo um americano, ser um sociólogo, é sempre solapada pela olhar fixador exterior.

- Chegue mais, quero lhe apresentar a meu colega negro... Aimé Césaire, homem negro, professor da Universidade... Marian Anderson, a maior cantora negra... Dr. Cobb, o descobridor dos glóbulos brancos, é um negro [...] A náusea. Quando me amam dizem que o fazem apesar de minha cor. Quando me detestam, acrescentam que não é pela minha cor... Aqui ou ali, sou prisioneiro do círculo infernal. (Fanon, 2008, p. 109)

$\mathrm{O}$ destaque dado à dupla consciência carrega uma verdade profunda que não queremos negligenciar, até porque C. L. R. James é, para o London Times, o "Platão Negro".

Quando falamos, então, em intelectuais afro-caribenhos mas que vale para o espaço da diáspora como um todo - devemos ter em mente que as construções intelectuais desses autores foram feitas desde posições ambíguas, que ora estão dentro e ora estão fora dos processos tidos como "normais"29. As perguntas de Bourdieu e de Mansbridge apontam, cada uma em sua medida, para um dos polos da dupla consciência. A de Bourdieu aponta ao que faz um intelectual, em termos de estratégias adotadas pelos agentes em suas circulações pelo espaço social, a de Mansbridge ao que faz um su-

29 Gilroy (2012) realiza essa discussão e seu clássico O Atlântico Negro pensando o sujeito negro como alguém que se encontra dentro e fora da modernidade ao mesmo tempo. 
Trajetórias através de um prisma:

Caribe, raça e consciência oposicional em C. L. R. James e oliver C. Cox

jeito subalterno que tem a psicologia construída pela opressão. Um engajamento que dê conta da multivocalidade e multilocalidade da experiência afro-diaspórica deve levar a sério raça não apenas como conceito analítico, mas como uma perspectiva epistemológica: é assim que lemos o prisma.

Gurminder Bhambra (2007) destaca que gênero, sexualidade e raça têm ganhado espaço na explicação sociológica, mas têm sido organizados dentro de ordens e categorias pré-existentes. "Em outras palavras, enquanto pode ter havido reconhecimento das reinvindicações de gênero, sexualidade ou raça no interior das abordagens sociológicas padrões, há também a tentativa de proteger as categorias centrais de análise de qualquer reconstrução que tal reconhecimento implicaria." ${ }^{30}$ (Bhambra, 2007, p. 873) A autora lê a história da Sociologia operando a partir duas categorias essenciais que ela distingue: sistema e a noção de (moderno) social. As críticas feministas à Sociologia puderam ser incorporadas na medida em que, do ponto de vista das pesquisas empíricas, poderia atentar-se à categoria gênero como uma clivagem do social (e portanto, "nãosistêmica"), e algo similar aconteceu com sexualidade.

Compreender o modo pelo qual a Sociologia foca o social, como distinto do sistema, e ao mesmo tempo cria uma estrutura na qual a relação com o 'sistema' se localiza, é de primordial importância. [...] é essa compreensão da Sociologia em termos de uma divisão siste$\mathrm{ma} /$ social e sua relação consequente com a ideia de Teoria Geral que coloca os limites fundamentais dos projetos sociológicos. Assim, o fracasso do feminismo e da teoria queer - as 'revoluções ausentes' de gênero e sexualidade - em afetar a transformação das categorias disciplinares da Sociologia repousa em sua reprodução dos mesmos aspectos da Sociologia que constituem o problema em primeiro lugar. $^{31}$ (Bhambra, 2007, p. 876)

Nesses casos, o que se viu foi a incorporação de elementos não na dimensão sistêmica, o que não afetou as estruturas da explicação Sociológica.

30 Tradução livre.

31 Tradução livre.

302 Século XXI, Revista de Ciências Sociais, v.9, nº 1, p.283-322, jan./jun. 2019 
Já o tema do pós-colonialismo, para Bhambra, aparece distante da incorporação de ambos o sistema e do social. A Sociologia, desse modo, sempre esteve mais aberta a trabalhar com raça enquanto uma clivagem do social, mas não com um engajamento crítico com a história do colonialismo, que implicaria em última instância a demolição de seu edifício teórico e conceitual. Há uma acomodação das clivagens de gênero, sexualidade e raça à questão de identidades. "Ao localizar gênero, sexualidade e raça no domínio do 'social', eles se tornaram questão para se falar sobre, mas não foram permitidos em si a desafiar as estruturas de diálogo que facilitam o reconhecimento e geral compreensão conceituais no mundo." 32 (Bhambra, 2007, p. 879) O que se precisa é encontrar um modo de aliar as implicações profundas que gênero, sexualidade e raça encerram, de modo a reconstruir nossas teorias, uma tarefa que, para a autora, o tema do pós-colonialismo é capaz de executar. Nossa abordagem reconhece essa urgência, e é nesse sentido que o prisma aparece em nosso estudo sobre Cox e James.

Esse aspecto sinaliza que uma leitura formal das trajetórias, embora dotada de relevância sociológica, corre o risco de ser parcial, de não capturar a estrutura de sentimento mais geral - em termos de Gilroy (2012) - que as sustenta. No limite, construir o conhecimento a partir do lado de cima da linha do humano, a zona do ser, permite apenas ver essa estrutura de sentimento como uma série de afinidades eletivas, ou seja, como convergências analógicas entre experiências pretensamente distintas em termos de contextos sócio -históricos, ou então enquadrar a questão racial através das lentes do 'estigma' (Goffman, 2012), feridas interacionais, trunfos ou handicaps presentes na circulação pelo espaço social.

Por um lado, ambos Cox e James estiveram sujeitos às lógicas de funcionamento dos campos nos quais ingressaram ou tentaram ingressar. James muda-se para a Inglaterra com o objetivo de ser escritor, e assim que chega vai morar em Bloomsbury. Cox, ciente do significado da carreira de Direito em Trinidad, ingressa na Northwestern University. Escrevem obras em diálogo com a tradição, a criticam, assumem posições específicas nos debates. Por outro lado, 32 Tradução livre. 
suas produções contêm uma afirmação estética e/ou política radical da existência do ser negro em um mundo que tenta constantemente negá-la, e os objetivos dos autores aqui não podem ser rastreados apenas às dinâmicas de funcionamento dos campos ou das redes intelectuais (Collins, 2000).

Isso explica a necessidade que o sociólogo americano Aldon Morris sentiu de deslocar a discussão sobre Escolas de pensamento estabelecidas por intelectuais negros para dar conta desses elementos negligenciados. Em seu livro The Scholar Denied, acerca da escola de Sociologia que W. E. B. Du Bois coordenou na Universidade de Atlanta, Morris se pergunta: "pode uma escola existir ainda que suprimida por um século?"33 (Morris, 2015, p. 168) Ou seja, como pode ser influente a produção de uma escola de autores negros se hoje ela aparenta ser desconhecida a muitos? Morris responde às questões através de um debate com tradições da Sociologia do conhecimento, e leva insights dessas tradições a regiões inexploradas, na tentativa de conciliar os recursos analíticos oferecidos com a particularidade da experiência negra e a trajetória ou redes de intelectuais subalternos. Centrais para Morris foram Bourdieu, com o conceito de capital, e Randal Collins e Robert Merton. Em diálogo com o primeiro, Morris argumenta que em se tratando de acadêmicos oprimidos e sem recursos, um outro tipo de capital entra em jogo, tão ou mais importante que os outros; o capital de libertação (liberation capital). "Consiste em trabalhos de pesquisa e outras atividades acadêmicas voluntários ou simbolicamente pagos, providas por um grupo autoconsciente de profissionais e trabalhadores intelectuais amadores para uma escola subalterna de pensamento que visa a desafiar os fundamentos intelectuais da opressão." 34 (Morris, 2015, p. 188) Com os últimos, Morris concorda que redes intelectuais são necessárias para a produção de uma obra original, mas discorda da necessidade implícita aí de que são necessárias redes de elite. O projeto de Du Bois e da Escola de Atlanta, para o autor, é melhor caracterizado como uma rede intelectual insurgente (insurgent intellectual network). Elas são "construídas por intelectuais subalternos a que - por causa do império, raça, classe el

33 Tradução livre.

34 Tradução livre. 
ou discriminação de gênero - foi negado o acesso a redes intelectuais de elite. ${ }^{35}$ (Morris, 2015. p. 193)

O contraste entre as trajetórias que nos propusemos a realizar nesta artigo, então, pressupõe a construção ontológica do ser negro preconizada por Fanon discutida mais acima e a produção intelectual desses autores como fugas epistemológicas, ao mesmo tempo em que não se mantém alheia às variáveis sociológicas mais gerais que ordenam os horizontes de possibilidade de produção, circulação e recepção de tais fugas. É nesse sentido que falamos de uma "produção social" da consciência oposicional descrita como prisma de formação caribenha, ou seja, nos interstícios entre o funcionamento da linha de cor global e as experiências sociais particulares de cada autor.

O desafio aos fundamentos intelectuais da opressão de que fala Morris implica no deslocamento de narrativas que mencionamos. Os intelectuais afro-caribenhos tiveram que trabalhar nas fendas dos discursos que tentavam construí-los como não-humanos e levar os argumentos a regiões que César nunca conheceu ${ }^{36}$. James o fez com um tipo de marxismo e o humanismo britânico, Cox com a Sociologia. Cedric Robinson, que chama tais práticas de "literatura oposicional", destaca o caráter subterrâneo que muitas vezes elas tiveram que assumir:

Como as representações diretas de oposição eram facilmente colocadas em quarentena pelas agências do conhecimento autorizado, uma estratégia subterrânea mais sutil evoluiu. C. L. R. James, por exemplo, em Mariners, Renegades and Castaways e em Beyond a Boundary, infiltrou-se nos códigos narrativos dos discursos hegemônicos americanos e britânicos através de críticas ao Moby-Dick de Melville e ao jogo de críquete respectivamente. Um segundo intelecto negro radical que empregou essa abordagem (e com maior sucesso) foi Oliver Cox. ${ }^{37}$ (Robinson, 1990, pp. 8-9)

\footnotetext{
35 Tradução livre.

36 "Se as ideias se originaram nas Índias Ocidentais, foi apenas na Inglaterra e na vida e história Inglesas que eu fui capaz de segui-las e testá-las. Para estabelecer sua própria identidade, Caliban, depois de três séculos, teve que ele próprio desbravar regiões que César nunca conheceu." (James, 1983, p. 9, tradução livre)

37 Tradução livre.
} 
Trajetórias através de um prisma:

Caribe, raça e consciência oposicional em C. L. R. James e oliver C. Cox

O movimento, então, de produção das obras envolve dois processos disputados e negociados na subjetividade dos autores, que devem afirmar-se como intelectuais e lidar com as exigências de seus estatutos ontológicos precários. "Sociólogos negros foram caracterizados por um dualismo enraizado em suas identidades como 'sociólogos-acadêmicos' e 'membros de uma categoria racial ou étnica' que 'engendra ambiguidades de status, conflitos de papéis, isolamento e contenção." "38 (Meier, 1977, p. 259) É seguindo nessa direção que daremos atenção agora às trajetórias de Cox e James.

\section{TRAJETÓRIAS ATRAVÉS DO PRISMA}

Ao se contrastar as trajetórias inicias de Oliver Cox e C. L. R. James, a primeira coisa que salta à vista são os pontos de chegada de cada um. James foi consagrado como um dos principais intelectuais do Atlântico Negro, e a quantidade de estudos sobre sua obra continua a crescer (Høgsbjerg, 2014). Oliver Cox pode ser considerado um sociólogo esquecido (Hunter, 1983), viu seu livro Caste, class and race enterrado pela editora Doubleday menos de um ano após o lançamento, que deixou de imprimi-lo após esgotada a primeira impressão (Sweezy, 1987), e produziu escritos tão impopulares nos “anos $1950 e$ 1960 que foi obrigado a pagar $\$ 2000$ e $\$ 2500$, respectivamente, para ter [seus outros livros] The Foundations of Capitalism e Capitalism and American Leadership publicados." ${ }^{39}$ (Hier, 2001, p. 72)

Pode-se objetar que os escritos de Cox não merecessem tal crédito, que menos as condições sociais de recepção e validação do que o conteúdo de sua obra foi determinante para seu esquecimento. Sobre esse aspecto, convém fazer duas observações. A primeira é que quando foi publicado Caste, class and race, em 1948, as avaliações não foram todas negativas. É evidente que autores como Allison Davis ou Everett Hughes, mais envolvidos nas disputas em relações étnico-raciais, responderam negativamente ${ }^{40}$. Outros autores, embo-

38 Tradução livre.

39 Tradução livre.

40 Everett Hughes chama o livro de Cox de "desapontador" por seus ataques pessoais: "Porque é desapontador descobrir que um autor dessa qualidade obscureceu onde ele declara esclarecer pelo uso da máxima sofística. Que ele transforme todo seu trabalho, por meio de uma distorção verbal colossal, em um argumento ad homines. Que ele agrave tudo isso ao usar livremente, sem 
ra incomodados com a linha marxista, apostavam que o livro "seria bem recebido por acadêmicos e cientistas sociais, especialmente depois que absorverem o choque do livro que tenta transcender o óbvio e penetrar radicalmente na natureza das dinâmicas sociais." ${ }^{\prime \prime}$ (Hill, 1948, p. 169) Ou que estavam diante de uma obra que traria "soluções" ao tema das relações raciais: "Quando o leitor virar a última página deste livro provocador, ele estará certo que o autor não apenas examinou criticamente algumas dessas pedras-de-toque, mas contribuiu para possíveis soluções no campo das relações raciais. ${ }^{\prime 42}$ (Blizzard Jr, 1948, p. 357)

A segunda observação corresponde à recepção da obra em outros tempos e espaços. Não obstante o livro ter sido silenciado por décadas na América, encontrou um importante simpatizante do outro lado do Atlântico. Hoje tido como uma das principais referências sobre o sistema de castas, Louis Dumont avaliou positivamente Caste, class and race em Homo Hierarchicus, publicado quase vinte anos depois. Cox é referenciado poucos momentos em Dumont, mas quando no Apêndice $A$ o autor volta-se a crítica ao uso de casta em relações raciais, apoia-se primordialmente sobre os textos de Cox:

A crítica à "Escola de castas de relações raciais" foi notavelmente levada adiante por Oliver C. Cox. Das mesmas fontes que Warner, Cox, com um insight admirável, pintou um quadro do sistema de castas infinitamente mais verdadeiro do que aquele com o que Warner se satisfazia. É verdade que não podemos sempre concordar com Cox, mas devemos lembrar que ele estava trabalhando com fontes de segunda ou mesmo terceira mão (por exemplo, de Bouglé). ${ }^{43}$ (Dumont, 1980, pp. 254-255)

\footnotetext{
crédito, o as ideias de seus oponentes que ele aprova, e nomeá-las apenas com o propósito de atacá-las." (Hughes, 1948, p. 66, tradução livre) Allison Davis é muito mais agressivo na escolha de palavras e chama o livro de "Alice no País das Maravilhas da Sociologia", "Todos estamos familiarizados com a observação cínica do francês de que a função usual das palavras é dissimular o pensamento. O livro mais recente do Dr. Oliver Cromwell Cox, Caste, Class and Race, deve ser visto por todos estudantes honestos do comportamento humano como um exercício extraordinário da falsa arte de tratar palavras não como símbolos de realidades comportamentais, mas como meios para negar a realidade; ou seja, criar um mundo obscurantista no qual o teste da verdade já não é mais a observação e inferência científicas, mas destreza ao fazer malabarismo com os próprios simbolos." (Davis, 1948, p. 161)

41 Tradução livre.

42 Tradução livre.

43 Tradução livre.
} 
Trajetórias através de um prisma:

Caribe, raça e consciência oposicional em C. L. R. James e oliver C. Cox

Em uma nota, Dumont completa que Cox era o único opositor sistemático à vertente, e que sua perspectiva parece ter "ganhado o dia" (Dumont, 1980, p. 421) É difícil saber o que Dumont quis dizer exatamente aqui, mas vale notar que os anos 60 foram o limite para os propósitos teóricos do uso de casta por uma impossibilidade de contexto (McKee, 1993) - a dessegregação e as lutas por direitos civis não podiam ser explicadas pela Escola de Castas -, e se a perspectiva de Cox "ganhou o dia" nesse sentido, não parece, portanto, decorrência da força dos argumentos.

Em tempos mais recentes, outros autores começaram a expressar sua dívida e influência por Cox. A explanação do autor para a origem do racismo com a invasão e conquista da América em 1492 está em sintonia com algumas das principais teses hoje promulgadas pela crítica, em geral latino-americana, chamada de decolonial ${ }^{44}$. Entre as teses está o reconhecimento, por parte de Cox, da reconfiguração do eixo no olhar ocidental do Mediterrâneo para o Atlântico ${ }^{45}$, um dos argumentos desenvolvidos por Mignolo (2007; 2011). Outro autor decolonial, Ramón Grosfoguel, destaca a herança:

Contrário a algumas teorizações que pretendem colocar Wallerstein como a origem da teoria do sistema-mundo, ou Quijano como a origem da ideia de que o racismo é um fenômeno produzido pelo mundo moderno a partir da expansão colonial europeia de 1492, essas teorizações já se encontram no intelectual afro-trinitino Oliver C. Cox desde os anos 40 e 50 do século passado. ${ }^{46}$ (Grosfoguel, 2016, p. 156)

Sobre Immanuel Wallerstein, que Grosfoguel menciona na fala acima, esse autor escreveu um texto em uma coletânea de 2000 na qual reconhece sua dívida, que "Oliver C. Cox expôs nos anos 50 e 60 virtualmente todas as ideias básicas da análise do sistema-mundo. Ele é um pai fundador, ainda que um dificilmente re-

44 Entende-se aqui a complexidade do termo, principalmente em vistas das disputas mais recentes que marcam esse grupo acerca de quem realmente se enquadra na perspectiva. Em todo caso, em língua portuguesa é importante mencionar o trabalho de Luciana Ballestrin (2013), que mapeia e lista alguns dos principais nomes do grupo Modernidade/Colonialidade.

45 A "sociedade moderna - a civilização ocidental-começou a adquirir seus atributos específicos quando Colombo voltou os interesses e olhos do mundo para longe do Mediterrâneo em direção ao Atlântico." (Cox, 1948, p. 330, tradução livre)

46 Tradução livre. 
conhecido como tal, e é amplamente negligenciado, mesmo hoje."47 (Wallerstein, 2000, p. 174)

Por fim, a Associação Americana de Sociologia modificou o título do prêmio que dá a trabalhos em relações raciais em 2006 para Cox-Johnson-Frazier Award, em homenagem a Cox, o primeiro a recebê-lo ${ }^{48}$. É difícil, portanto, afirmar que o silenciamento lançado sobre Cox corresponda a irrelevância profissional. Existem fatores específicos que concernem um sistema de legitimações e o lugar reservado para as vozes dissidentes negras na academia americana.

Stuart Hall, sobre sua irmã que teve um colapso mental quando seu relacionamento com um estudante de medicina de Barbados, mais escuro que ela, foi proibido por seus pais, comenta em uma entrevista que desde então, nunca mais pôde "entender por que as pessoas achavam que essas questões estruturais não estavam ligadas ao psíquico - com emoções, identificações e sentimentos, pois para [ele], essas estruturas são coisas que a gente vive." (Hall, 2009. p. 390) A formação caribenha e os graus diferentes de sucesso adquiridos por Cox e James sob a égide do colonialismo moldaram desde o princípio a percepção dos horizontes de possibilidades de cada autor. James deixa Trinidad com 31 anos, tendo estudado e lecionado no melhor colégio da ilha, jogado críquete profissionalmente e fundado revistas literárias posteriormente importantes para a história cultural do Caribe. Randal Collins chama atenção que o acesso a redes intelectuais de elite, e principalmente as interações face-a-face que elas possibilitam, carregam os sujeitos de "energia emocional", que funcionam como uma "bateria" para processos de criatividade intelectual.

Os encontros têm um rescaldo emocional; é por essa rota que pessoas podem perseguir suas vidas interiores e suas trajetórias individuais, e ainda serem moldadas pelos nodos da interação social. A energia emocional se esgota após um período de tempo, para renová -la, os indivíduos são levados de volta à participação ritual para se recarregarem. ${ }^{49}$ (Collins, 2000, p. 23)

47 Tradução livre.

48 O título antes era DuBois-Johnson-Frazier Award. Para informações sobre o prêmio consultar o site da instituição: http://www.asanet.org/news-events/member-awards/cox-johnson-frazier-asa-award .

49 Tradução livre. 
Trajetórias através de um prisma:

Caribe, raça e consciência oposicional em C. L. R. James e oliver C. Cox

É por isso que James conseguia, na Inglaterra ${ }^{50}$, não ressentir-se de maneira profunda com experiências pessoais de discriminação, ou mesmo afirmar que pertencia a Bloomsbury, e em menos de cinco anos no país escrever uma história compreensiva da internacional comunista.

Cox frustra-se sobremaneira com sua formação e se ressente do lugar que ela a reservou após conseguir aprimorá-la em Chicago. Mas há fatores determinantes aqui. Em uma conferência de 1971, C. L. R. James discute Caste, class and race e destaca o que considera a principal diferença entre si e Cox:

O livro [World Revolution 1917-1936: The Rise and Fall of the Communist International] foi escrito em 1937. Este [Caste, Class \& Race] foi escrito em 1947, mas em 1937 eu já tinha ido muito além de onde Cox estava. E isso não porque eu sou inteligente, mas porque eu estava trabalhando na Europa. Eu não poderia ter escrito esse livro sem a acumulação imensa de material e ideias que os trotskistas coletaram. Cox estava trabalhando praticamente sozinho nos Estados Unidos. Eu não sei se ele foi alguma vez membro do Partido Comunista, mas ele decidiu que o método deles não era o dele, e estava trabalhando independentemente sobre isso. Estou tentando fazer vocês entenderem que o livro é resultado de uma força socialista. Eu não poderia ter escrito este livro sozinho. ${ }^{51}$ (James, 2016, Online)

Ao que tudo indica, Cox não foi membro do Partido. Seja como for, James está correto em enfatizar as redes a que teve acesso na Inglaterra. Do ponto de vista político, Cox saiu cedo demais de Trinidad para acompanhar a greve dos trabalhadores das docas de 1919 - que afetou James principalmente em sua veia anticolonial - e, uma vez nos Estados Unidos, cortou qualquer janela ao que Kent Worcester (1996) chamou de hábitos plebeus (McAuley, 2004), como o críquete ou o calypso. James, ao contrário, na Inglaterra aguçou uma consciência política em contato com as movimentações proletá-

50 A situação é diferente nos EUA. Em 1939, após uma série de conversas com Trostsky no México - nesse momento exilado em Coyoacán -, James decide retornar a Nova Iorque de ônibus, o que significou atravessar o Sul dos Estados Unidos, do qual ele não conhecia os códigos do Jim Crow. Conta-se que após voltar, James passou uma semana sem falar com seus colegas de partido brancos (EVERY, 2016).

51 Tradução livre. 
rias de Nelson, que ao mesmo tempo, como ressalta, deu-lhe acesso a uma ampla literatura radical.

Allison Davis, em sua resenha crítica ao livro de Cox, não deixa de mencionar o fato curioso de Cox não citar $O$ Capital de Marx em Caste, class and race, mas apenas Contribuição à crítica da Economia Política e O Manifesto Comunista. "(De fato, Dr. Cox demonstra apenas um conhecimento superficial de Marx, deixa a entender que descobriu as ideias de Marx independentemente, não inclui Das Kapital em sua bibliografia e lista apenas traduções inglesas de Marx.)"52 (Davis, 1948, p. 161) Ainda que James se dedique a uma leitura sistemática de $O$ Capital apenas quando se muda aos Estados Unidos ${ }^{53}$, na Inglaterra participava de grupos de estudos - um deles na casa de um pesquisador de câncer em Hampstead Garden - de autores radicais e tinha contatos pessoais diretos com membros do Comintern, como seu amigo George Padmore. Desse modo, as atividades no ILP e em grupos como o IAFA permitiram que, no caso de James, a formação política acompanhasse a formação intelectual. No caso Cox, elas foram separadas.

A solidão de Cox é um fator que também deve ser considerado porque penetra sua vida profissional e pessoal ${ }^{54}$. Os relatos sobre esta são escassos, mas ao que parece não só trabalhou em isolamento como viveu em isolamento, nunca se casou e viveu 21 anos em um apartamento de dois cômodos no dormitório estudantil da Universidade de Lincoln - onde lecionou após deixar Tuskegee em 1949 (McAuley, 2004. p. 61). Barbara Celarent coloca como hipótese que esse aspecto motiva, de alguma forma, a crítica que Cox fez à Escola de Castas. "É possível se perguntar, de fato, se Cox se sentiu tão isolado ao ponto de pensar que não teria nada a perder. Talvez ele já estivesse no caminho do ressentimento que produziu sua denúncia vitriólica nos anos 60 do mais famoso sociólogo negro de

52 Tradução livre.

53 James sumariza esse ponto em uma carta de 1939 a sua futura segunda esposa, a atriz Constance Webb: "E agora sobre Das Kapital. Minha cara jovem mulher, eu tenho algumas notícias para você. Um tal de C. L. R. James, declarado marxist, tendo pensado sobre sua vida passada e expectativas futuras, deciidu que o que ele precisa agora é de um trabalhoso estudo de? Adivinha! A Bíblia? Errado. O Touro Ferdinando? Errado de nodo. Não seria o Das Kapital? Sim, e eu terminarei esses três volumes e nada além de uma revolução irá me impedir." (James apud Bogues, 1997, p. 53, tradução livre)

54 A deficiência de Cox pode ter tido um papel em seu isolamento de fato e emocional, mas é difícil precisar até que ponto. 
Trajetórias através de um prisma:

Caribe, raça e consciência oposicional em C. L. R. James e oliver C. Cox

sua era [Frazier]."55 (Celarent, 2011, p. 1667) Já James não poderia ser mais o oposto. Informações sobre sua vida pessoal são abundantes e polêmicas. Casou-se três vezes e exercia uma sexualidade que contrastava com sua educação puritana. Na Inglaterra, podia ser descrito como um bon vivant ${ }^{56}$, nos Estados Unidos teve relações sexuais com "inúmeras" mulheres da tendência política dissidente que estabeleceu com Grace Lee Boggs e Raya Dunayevskaya, esta com quem também se relacionou ${ }^{57}$ (Johnson, 2011, p. 195).

Em termos de ingresso dessas duas vozes intelectuais afrocaribenhas na vida intelectual do século XX, então, parece ter sido determinante o acesso a movimentos políticos uma vez que eles implicavam uma formação radical mais orgânica. Cox nunca foi um dissidente, e seu radicalismo intelectual ia de encontro ao seu conservadorismo político. Soma-se a isso o horizonte de possibilidade que as diferentes gramáticas de racialização propiciaram nos dois contextos, Inglaterra e Estados Unidos. O racismo não impedia que a população de Nelson, Lancashire, pudesse ser curiosa com a presença de negros como James e Learie Constantine, e estava disposta a ouvi-los palestrar e participar politicamente, o que não era tão diferente em Londres. Nos Estados Unidos, a linha de cor relegava um lugar muito particular para o sujeito rebelde negro.

Em todo caso, ambos James e Cox sentiram a necessidade de levar adiante a questão racial como uma variável crítica para o deslocamento e renovação dos discursos políticos e intelectuais. Veja que o engajamento sobre o tema de raça e sua interface com o surgimento da modernidade é comum aos dois. Esse ponto merece uma consideração mais detida uma vez que nos parece que é na articulação entre a experiência do racismo e o marxismo que se pode compreender alguns dos rumos que as vidas dos autores tomam. James era declaradamente marxista, Cox negava a atribuição (McAuley, 2004). Há uma tendência, cujo principal expoente parece ser Cedric Robinson, que afirma a existência de um marxismo ne-

55 Tradução livre.

56 "Imensamente amável, ele [James] amava as farturas do capitalismo: boa comida, boas roupas, bons móveis e belas mulheres sem nenhum traço de culpa ou remorso que poderia se esperar de um experiente guerreiro da luta de classes." (Warburg apud Høgsbjerg, 2014, p. 8, tradução livre) 57 Sobre a relação entre sexualidade, gênero e seu impacto sobre James ver: Sex and the subversive alien: The moral life of C. L. R. James (Johnson, 2011). 
gro (2000), ou seja, que autores como James e Cox, sendo este um marxista, trouxeram algo ao marxismo que ele não poderia saber sozinho; a experiência do racismo e a herança dos horrores de séculos de opressão. Há outra, por exemplo em Anton Allahar, que prefere, na equação "marxismo + negro" enfatizar mais aquele que este, na medida em que o reconhecimento de "raça" como uma variável explanatória geral não desqualificaria o rótulo de marxista (Allahar, 2014, p. 426). A questão aqui oscila, então, na consideração de se o deslocamento trazido por intelectuais negros mantém ou não intacto o bloco de conhecimento a que se refere. Nossa posição deve estar clara até agora, que os aportes de autores como James e Cox levaram os discursos a lugares muito diferentes de onde surgiram. Ademais, parece que a primazia analítica da origem, como o marxismo, sobre o deslocamento, raça, está mais preocupada em preservar os preceitos daquela do que considerar as críticas e contribuições deste. Esse aspecto fica claro ao final da exposição de Allahar: "Graças à Oliver Cox e C. L.R. James, dois neomarxistas de boa-fé, que, trabalhando na tradição marxista, mantiveram as questões de classe e análise de classe o foco de atenção de nossos pensamentos e nossa práxis." ${ }^{58}$ (Allahar, 2014, p. 441. grifo nosso)

A ênfase sobre a articulação entre marxismo e questão racial permite uma compreensão melhor sobre as dinâmicas que promoveram a consagração de James e a marginalização de Cox nas fases iniciais de suas trajetórias. É necessário ressaltar que em nenhum momento apreendemos a vida dos autores como uma totalidade coerente e autossustentada, mas nos aproximamos da ideia de "trajetória", como um destaque analítico que reside na "série de posições sucessivamente ocupadas por um mesmo agente (ou mesmo um grupo), em um espaço ele próprio em devir e submetido a transformações incessantes." (Bourdieu, 1996b, p. 81) Os autores, assim, circulavam por esses espaços dinâmicos. O debate de James estava no interior do marxismo, com as propostas políticas e as formas de compreensão. Mais ainda, no interior de um grupo particular, os trotskistas, que na Inglaterra eram minoritários e desorganizados, o que possibilitou a James tomar frente nos debates sem grandes oposições a si e à 58 Tradução livre. 
Trajetórias através de um prisma:

Caribe, raça e consciência oposicional em C. L. R. James e oliver C. Cox

circulação de pautas heterodoxas. Quando parte aos Estados Unidos em 1938, o fez na condição de um dos principais nomes do movimento e responsável por desenvolver um programa revolucionário na temática racial a convite do próprio Trostsky (Bogues, 1997, p. 51), com quem se sentiu confortável para romper politicamente alguns anos depois e traçar um caminho independente.

Cox, por sua vez, não estava engajado em movimentações políticas, e sua preocupação era o exercício acadêmico da Sociologia na América. Por uma série de eventos, foi levado a uma literatura que estava distante dos projetos teóricos de Chicago, e a preocupações investigativas que eram muito mais propícias na Europa do que nos Estados Unidos. O marxismo aparece para o autor como uma ferramenta explicativa ${ }^{59}$, não como um comprometimento político no sentido de James. Essa fórmula pareceu perigosa para seus pares, e quando o autor a utiliza para atacar os preceitos que sustentavam as reflexões em relações raciais, acabou por pagar o preço. Nos primeiros anos da Guerra Fria, ser "comunista" afetava de maneira significativa os rumos das carreiras. As resenhas imediatas ${ }^{60}$ à publicação de Caste, class and race criticaram esse aspecto. Howard Becker se recusou a escrever a introdução do livro por suas "tendências comunistas" ${ }^{\prime \prime}$, e os editores se recusavam a publicar os trabalhos de Cox pelos mesmos motivos $^{62}$. Um deles, William Selgby, respondeu em uma carta: "Caro professor Cox. É inútil, não consigo digerir a linha comunista." $"$ (Selgby apud Martin, 1971, p. 22)

Entretanto, parece-nos que o comunismo de Cox está articulado a algo mais fundamental. A perspectiva de que o autor foi enterrado pelo seu alinhamento deve ser vista com algumas ressalvas.

59 "Assim, se partes deste estudo parecem marxistas (Marxian), não é porque tomamos as ideias deste justamente famoso autor como evangelho, mas porque não descobrimos nenhum outro que pudesse explicar os fatos de forma tão consistente." (Cox, 1948, p. xi, tradução livre)

60 Ver: (Hill, 1948; Blizzard Jr, 1948; Davis, 1948; Hughes, 1948)

61 Becker respondeu a Cox em uma carta: "Depois de uma intensa, profunda e muito dolorosa segunda leitura de seu manuscrito, eu sou forçado a dizer que seria absolutamente impossível para mim escrever uma introdução ao seu livro que não fizesse mais mal do que bem. Seu marxismo é tão indiluído, especialmente na parte sobre classe e na conclusão, que eu teria que me dissociar completamente. E completa: "Eu não sei quem é sua editora, mas eu ficaria imensamente surpreso - assumindo que seu examinador seja prudente - se ele aceitasse o livro sem modificações." (Becker apud Hunter, 1987, p. xxxiii, tradução livre)

62 Para mais informações sobre a acusação de comunismo contra Cox, consultar a segunda parte da dissertação de Elmer Martin (1971).

63 Tradução livre. 
Outros autores contemporâneos a Cox, negros e brancos, também tinham tendências marxistas e não tiveram o mesmo destino. Para fins de comparação, E. Franklin Frazier, negro que passou por Chicago, também partilhava a influência da análise dialética marxista, de acordo com Anthony Cheeseboro. No entanto, Frazier optou por dissimular sua influência, mesmo quando fazia críticas que eram claramente marxistas - como em Black Bourgeoisie. "A principal diferença na estatura acadêmica dessas duas importantes figuras pode ser atribuida a suas abordagens diferentes dos paradigmas aceitos por acadêmicos estabelecidos em seus campos. Cox desafiou diretamente esses paradigmas, enquanto a abordagem de Frazier era mais oblíqua." ${ }^{64}$ (Cheeseboro, 1999, p. 150) A questão, então, parecia estar no lugar que se reservava a crítica por parte dos intelectuais negros.

Assim, não é uma questão exclusivamente racial, tampouco exclusivamente de filiação política, que explica a marginalização de Cox, mas sim uma articulação desses elementos, que dispôs Cox a tomar posição contra o lugar que lhe era designado. Sean Hier contrasta em um trabalho os resultados dos desenvolvimentos sobre o sistema-mundo de Wallerstein e Cox. Depois de um escrutínio crítico sobre as contribuições de ambos os autores, indica que o marxismo não foi sozinho a principal variável. Wallerstein bebeu da mesma água, e embora se possa objetar que o ambiente dos anos 60 e 70 dos Estados Unidos fosse mais aberto a ideias radicais, ainda assim recebeu um reconhecimento muito maior. Cox foi lido como um comunista, era negro e rebelou-se. "A rigidez das barreiras raciais era equiparada à rigidez das barreiras intelectuais. Cox tentou quebrar ambas. ${ }^{\prime 65}$ (Hier, 2001, p. 83)

Se Cox tivesse escrito suas críticas em outro momento, teria o mesmo destino? É difícil saber. As atividades socialistas entre negros americanos durante as décadas de 60 e 70 tampouco foram mil maravilhas, vide as experiências de movimentos como Os Panteras Negras ou de intelectuais como Angela Davis e a controvérsia sobre sua expulsão da Universidade da Califórnia em 1969-1970. Além 
Trajetórias através de um prisma:

Caribe, raça e consciência oposicional em C. L. R. James e oliver C. Cox

disso, ativistas e intelectuais negros posteriores não perdoaram a solução assimilacionista promulgada por Cox desde os anos 40, o que complicou sua situação. Como diz Barbara Celarent, Cox foi então "pego pela letargia reputacional: muito fora de moda para ser ativamente debatido, muito ultrapassado para ser retrospectivamente imortalizado." ${ }^{\circ 6}$ (Celarent, 2011, p. 1664)

C. L. R. James residiu nos Estados Unidos até 1953, quando foi deportado. Sua vida permaneceu diaspórica: residiu no Caribe, Inglaterra, Estados Unidos novamente, Gana. Falece em 1989 em Londres como uma figura multifacetada ${ }^{67}$, a qual cada dia surgem novas publicações e celebrações. Cox leciona na Lincoln University até se aposentar em 1970. Cogita voltar a Trinidad, mas o que define como "problemas" - provavelmente sua deficiência - o fazem mudar de ideia. Acaba convidado a lecionar na Wayne University pelo chefe do departamento de Sociologia da instituição, que achava que Cox estivesse "muito solitário"68. Morre em 1974, provavelmente sem nenhuma pista dos caminhos que as leituras futuras de sua obra seguiriam.

Observar as trajetórias de Oliver C. Cox e C. L. R. James nos permitiu dar solidez empírica à interpretação de Hall sobre sua trajetória, à ideia de prisma. A proposta de que ele representa uma reação distintivamente caribenha aos processos de racialização é corroborada pelas semelhanças e diferenças nas trajetórias dos autores. Em ambos os casos, eles conseguiram levar adiante as críticas por estarem dentro e fora da modernidade, tanto em um sentido de inserção quanto - principalmente - de construção. C. L. R. James comenta esse fato em relação ao martiniquenho Aimé Césaire.

\footnotetext{
66 Tradução livre.

67 "Dada a pluriconsciência da identidade jamesiana -um negro mas ainda assim britânico, um nativo colonial mas ainda assim culturalmente parte do código da escola pública, atado à causa do proletariado mas assim membro da classe média, um marxiano mas ainda assim um puritano, um intelectual que joga críquete, um afro-descendente mas ainda assim ocidental, um trotskista e um pan-africanista, um marxista mas ainda assim apoiador dos black studies, uma maioria indiana ocidental negra mas ainda assim uma minoria americana negra-,era evidenteque a questão negra, e a figura de Matthew Bondman que espreitava por detrás, não poderia ser resolvida por um "ou um ou outro" -isto é, ou pela classe ou pela raça, proletariado ou trabalho escravo, ou condenados da terra, nacionalismo pan-africano ou internacionalismo trabalhista. A busca por um quadro que contivesse todos veio a constituir a poiesis jamesiana." (Wynter, 1992, p. 69, tradução livre)

68 "Eu acho que ele estava solitário, e que ficou muito contente que eu lhe havia convidado..." (Rose apud Hunter, 1987. p. xxix, tradução livre)
} 
Eu conversei com Césaire em Cuba outro dia. Gostei do trabalho dele. Ele sabia que eu tinha escrito sobre, e disse que gostava do meu. E eu perguntei a ele: "Onde, quando você começou?" Ele me disse que na Escola Victor Schoelcher, na Martinica. Uma escola muito boa no Caribe. Eu fui educado no Queen's Royal College, uma escola muito boa. Oito ou novo professores, todos homens de Oxford e Cambridge. Eles trouxeram alguma coisa, e eles nos ensinaram. Victor Schoelcher, Harrison College em Barbados, uma das famosas escolas clássicas no mundo, latim e grego. Mas havia muito poucos entre nós que pegamos. Educação que fomos pegando através das pessoas do continente que vinham de fora... Eu perguntei para ele onde ele começou, ele disse: "Eu comecei na Escola Victor Schoelcher." Eu disse: "o que você fazia lá?" Ele disse: "Latim e grego, e literatura francesa." A essência da civilização ocidental é latim e grego, e francês. Você pega a transferência disso no mundo moderno. Eu disse: "E então onde você se aventurou a ir?" Ele disse: "Eu fui para a École Normale Supérieure". Essa era uma escola famosa, a escola mais famosa da França. Notória principalmente por produzir grandes acadêmicos e comunistas. E eles produziram um em Césaire; ele se tornou membro do Partido Comunista. Eu disse: "o que você fazia na École Normale?" Ele disse: "Latim e grego, e literatura francesa." Eu disse: "E então?" Ele disse: "Eu fui para a Sorbonne." E eu disse: "O que você fazia na Sorbonne? Eu suponho que você fez a mesma coisa." "Sim. Latim e grego, e literatura francesa."

E ele [Césaire] disse: "Mas eu tenho outra coisa para te contar." Ele disse: "Eu voltei para lecionar na escola Victor Schoelcher," Mas, antes de ele voltar, ele escreveu a crítica mais devastadora da Civilização Ocidental feita no século XX. Isso é o "Cahier". Em outras palavras, ele atacou. Ele poderia atacá-la como fez porque a conhecia de dentro pra fora. Ele a passou estudando do tempo que tinha seis ou sete anos até ser um homem de vinte e cinco. Eles a ensinaram para ele, e isso era característico de todo indiano ocidental, e em certo sentido, essa é a influência dos europeus sobre o indiano ocidental. Cox não tinha isso. ${ }^{69}$ (James, 2016, Online)

69 Tradução livre. And he [Césaire] said, "But I have another thing to tell you.' He said, 'I went back to teach at the Victor Schoelcher School. 'But, before he went back, he wrote the most devastating critique of Western Civilization that has been done in the twentieth century. This is the 'Cahier.' In other words, he attacked it. He could attack it as he did because he understood it from the inside out. He had spent, from the time he was six or seven until he was a man of about twenty-five, studying it. They had taught it to him, and that was characteristic of every West Indian, and in a sense, that is European's influence upon the West Indian. Cox didn't have that." 
O comentário de James deixa de lado que apesar dos eventos que expulsaram Cox do universo de elite do Caribe e suas promessas, os esforços do autor na Universidade da Chicago o colocaram por dentro de um elemento principal da autoconsciência reflexiva da Civilização Ocidental, a Sociologia. Cox a conheceu também de "dentro para fora", e fez uma crítica devastadora que, é possível, só possa ter sido feita por ter vindo do Caribe. À diferença de James ou Césaire, ela passou despercebida, até mesmo para aquele.

Por fim, é importante fazer duas considerações finais e interligadas. Em primeiro lugar, não se tratou de afirmar neste trabalho que é propriamente o Caribe que gerou as consciências oposicionais de James e Cox, mas as condições de vida e certo sistema de disposições que o Caribe, negro e colonial, impôs. Em diferentes contextos os autores responderam de diferentes modos a sua influência, com resultados diferentes em ambos os casos, mas que se aventuraram em regiões que César nunca conheceu, e em consonância com as reflexões finais de Fanon em Os Condenados da Terra, tentaram pôr de pé um homem novo: Para a Europa, para nós mesmos e pela humanidade, camaradas, é preciso renovar-nos, desenvolver um pensamento novo, tentar pôr de pé um homem novo." (Fanon, 2005, p. 366)

Em segundo lugar, vale enfatizar que nossa abordagem colocou as disfunções no princípio. Significou perceber que as similaridades percebidas entre Cox e James e outros autores caribenhos, em termos de temas, abordagens e outras práticas intelectuais, não podiam ser explicadas simplesmente em termos de um contexto de influências. Afinal, como bem aponta Maia, partindo de La Capra, "a simples afirmação de que um determinado contexto influenciaria um texto não diria muito, uma vez que os modos como essa relação se dá são objetos constantes de pesquisa, e não pontos de partida metodológicos." (Maia, 2008, p. 14) Em nosso trabalho, foi justamente a perspectiva do prisma que permitiu capturar os modos dessa relação, algo não menos sociológico. 


\section{REFERÊNCIAS}

ALLAHAR, A. Marxist or not? Oliver Cromwell Cox on capitalism and class versus "race". Canadian Journal of Latin American and Caribbean Studies, Vol. 39, n³, pp.420-444, 2014.

BALLESTRIN, L. América Latina e o giro decolonial. Revista Brasileira de Ciência Política, nº11, pp.89-117, 2013.

BHAMBRA, G. Sociology and Postcolonialism: Another 'Missing' Revolution?. Sociology. Volume 41, nº5, pp.871-884, 2007.

BLIZZARD JR, S W. Caste, Class, and Race: A Study in Social Dynamics. American Sociological Review, Vol. 13, No. 3, pp.357-358, 1948.

BOGUES, A. Caliban's freedom: the early political thought of C. L. R. James. London - Chicago: Pluto Press, 1997.

BOURDIEU, P. É possível um ato desinteressado? In: Razões práticas. Campinas: Papirus, 1996a.

BOURDIEU, P. A ilusão biográfica. In: Razões práticas. Campinas: Papirus, 1996b.

BUHLE, P. The artist as revolutionary. New York: Verso, 1988.

CELARENT, B. Caste, class, and race by Oliver Cromwell Cox. American Journal of Sociology, Vol. 115, n5, pp.1664-1669, 2010.

COLLINS, R. The sociology of philosophies: a global theory of intellectual change. Cambridge and London: The Belknap Press of Harvard University Press, 2000.

COUlON, A. A Escola de Chicago. Campinas: Papirus, 1995.

COX, O C. Caste, class and race: a study in social dynamics. New York: Doubleday and company, 1948.

CUDJOE, S. C. L. R. James y la tradición intelectual de Trinidad y Tobago, o no se estudia Shakespeare debajo de un árbol de mango. New Left Review, no. 25, pp.127-142, 2004.

DU BOIS, W E B. As almas da gente negra. São Paulo: Lacerda, 1999.

DUMONT, L. Homo Hierarchicus: The Caste System and Its Implications. Chicago: The University of Chicago Press, 1980.

EVERY, Cook Can Govern: The Life, Impact \& Works of C.L.R. James. United Kingdom: WORLDwrite, 2016. 121 mins., Cor.

FANON, F. Os condenados da Terra. Juiz da Fora: Editora da UFJF, 2005. 
Trajetórias através de um prisma:

Caribe, raça e consciência oposicional em C. L. R. James e oliver C. Cox

Pele negra, máscaras brancas. Salvador: Edufba, 2008.

FAUSTINO, D. Por que Fanon, por que agora?": Frantz Fanon e os fanonismos no Brasil. 2015. 261 p. Tese (Doutorado em Sociologia) Universidade Federal de São Carlos, Programa de Pós-Graduação em Sociologia, São Carlos, 2015.

GILROY, P. O Atlântico Negro. São Paulo: Editora 34, 2012.

GOFFMAN, E. Estigma: notas sobre a manipulação da identidade deteriorada. Rio de Janeiro: LTC, 2012.

GROSFOGUEL, R. Caos sistémico, crisis civilizatoria y proyectos descoloniales: pensar más allá del proceso civilizatorio de la modernidad/colonialidade. Tabula Rasa. Bogotá - Colombia, №25, pp.153-174, julio-diciembre, 2016.

HALL, S. Epilogue: through the prism of an intellectual life. In: Culture, politics, race and diaspora. Kingston: Ian Randle Publishers, 2007.

. Pensando a diáspora: reflexões sobre a terra no exterior. In: $D a$ Diáspora: identidades e mediações culturais. Belo Horizonte: Editora UFMG, 2009.

. Familiar Stranger: a life between two islands. Durhan: Duke University Press, 2017.

HIER, S. The forgotten architect: Cox, Wallerstein and world-system theory. Race class, $\mathrm{n}^{\circ} .42$, pp.69-86, 2001.

HILL, M. Caste, Class, and Race: A Study in Social Dynamics. Social Forces, Vol. 27, №. 2, dez., pp.168-169, 1948.

HØgSBJERG, C. C. L. R. James in Imperial Britain. Durhan: Duke University Press, 2014.

HUGHES, E. P The Literature of Race and Culture. Phylon, Vol. 9, №. 1. Primeiro sem., pp.66-68, 1948.

HUNTER, H M. Oliver C. Cox: a biographical sketch of his life and work. Phylon, vol. 44, no. 4, pp. 249-261, 1983.

. The life and career of Oliver C. Cox. In: Race, class and the world system. New York: Monthly Review Press, 1987.

JAMES, C . L. R. Beyound a boundary. New York: Pantheon, 1983. Letters from London. Port of Spain: Prospect press, 2003. . Os jacobinos negros: Toussaint Louverture e a Revolução de São Domingos. Campinas: Boitempo, 2010. 
The class basis of the race question in the United States. New Politics. No 60, Vol XV-4, Winter 2016. n.p. Disponível em: http:// newpol.org/content/class-basis-race-question-united-states

JOHNSON, W C. Sex and the subversive alien: the moral life of C. L. R. James. International Journal of Francophone Studies. Vol 14, No 1\&2, pp.185-203, 2011.

JOHNSON, Y. Oliver C. Cox and the Chicago School of Sociology: Its Influence on His Education, Marginalization, and Contemporary Effect. Journal of Black Studies, Vol. 35, No. 1, pp. 99-112. 2004.

KELLEY, R. Introduction. In: JAMES, C. L. R. A history of pan-african revolt. Chicago: The Charles H Kerr Library, 2012.

LAMMING, G. The pleasures of exile. Ann Arbor: University of Michigan Press, 1992.

LASLETT, B. Biography as Historical Sociology: The Case of William Fielding Ogburn. Theory and Society. Vol. 20, №. 4, ago., pp.511$538,1991$.

MAIA, J M E. A terra como invenção: o espaço no pensamento social brasileiro. Rio de Janeiro: Zahar, 2008.

MALDONADO-TORRES, N. Sobre la colonialidad del ser: contribuciones al desarrollo de un concepto. In: El giro decolonial - Reflexiones para una diversidad epistémica más allá del capitalismo global. Bogotá: Iesco-Pensar-Siglo del Hombre Editores, 2007.

MANSBRIDGE, J. The making of oppositional consciousness. In: Oppositional consciousness: the subjective roots of social protest. Chicago: The University of Chicago Press, 2001.

MARTIN, E P. The sociology of Oliver C. Cox: a systematic inquiry. Dissertação - Atlanta University, 1971.

MCAULEY, C. The mind of Oliver Cox. Notre Dame: University of Notre Dame Press, 2004.

MCKEE. J. Sociology and the race problem: the failure of a perspective. Urbana and Chicago: The University of Illinois Press, 1993.

MIGNOLO, W. La idea de América Latina. Barcelona: Gedisa editorial, 2007.

. La colonialidade a lo largo y a lo ancho: el hemisferio occidental en el horizonte colonial de la modernidad. In: La colonialidad del saber: eurocentrismo y ciencias sociales: perspectivas latinoamericanas. Buenos Aires: CICCUS, 2011. 
MORRIS, A. The scholar denied: W. E. B. Du Bois and the Birth of Modern Sociology. Los Angeles: University of California Press, 2015.

PONTES, H. Círculo de Intelectuais e Experiência Social. Revista Brasileira de Ciências Sociais, vol.12, no 34, pp.57-69, 1997.

ROBERTS, N. Freedom as marronage. Chicago: The University of Chicago Press, 2015.

ROBINSON, C. Black Marxism: the making of a black radical tradition. Chapel Hill: The University of North Carolina Press, 2000.

Oliver Cromwell Cox and the Historiography of the West. Cultural Critique. №. 17, pp.5-19, 1990.

SEGAL, D. 'Race and 'colour' in pre-independence Trinidad and Tobago. In: Trinidad Ethnicity. London: The Macmilan Press, 1993.

SWEEZY, P. Foreword. In: Race, class and the world system. New York: Monthly Review Press, 1987.

THE, Great Debaters. United States: Harpo Productions, 2007. 126 mins., Cor.

TOLSON JR, M. The Poetry of Melvin B. Tolson (1898-1966). World Literature Today, Vol. 64, N. 3, pp.395-400, 1990.

WALLERSTEIN, I. Oliver C. Cox as world system analyst. In: The Sociology of Oliver C. Cox: New Perspectives. Bingley: Emerald Publishing Ltd, 2000.

WILLIAMS, R. Marxism and literature. Oxford: Oxford University Press, 1977.

WORCESTER, K. C. L. R. James: a political biography. New York: Suny Press, 1996. 